\title{
Islamic Philanthropy Development Model Based on Management of Waqf Treasure Improvement on the Mosques of the Northern Seaboard of Java
}

\author{
Hidayatus Sholihah \\ Islamic Studies Department \\ Universitas Islam Sultan Agung \\ Semarang, Indonesia \\ hida@unissula.ac.id
}

\author{
A. Zaenurrosyid \\ Islamic Studies Department \\ Universitas Islam Sultan Agung \\ Semarang, Indonesia
}

\begin{abstract}
Waqf in Islam was one of economic asset to make a balanced prosperity distribution for whole society. But, in fact there were many constraints to develop this waqf in future. One of them was civilizing nazhirs'choices in organising waqf that also resulted on differing models of distribution waqf productively.This study is of the dynamics of the institution of waqf in the great mosques of the northern seaboard of Java (Jawa pesisiran). It focuses on forms of waqf management by nazhirs. The main problem researched is about looking in depth at the effect of the nazhirs' culture on improving the management of waqf, which has resulted in differing models of waqf management.This study may be considered anthropological research into Islamic law. It is qualitative research supported by an academic approach. there are at least three models of culture in the processes of waqf management: traditional, semi-professional and professional. These research findings contribute to the theoretical construction of models of waqf distribution at the great institutional mosques of the Javan seaboard, which consistently implement improvements to the dynamic processes associated with waqf management in an Indonesia context.
\end{abstract}

Keywords: Waqf, Islamic Philanthropy, Mosque Improvement, Northern Seaboard of Java

\section{INTRODUCTION}

Islam came in this world by all of its law and values to give love and advantages societies. Islam is understood from its holy book, which is oriented for all human kind in this universe. The vision of Islam as rahmatan li al alamin is the essential teaching for better life in this world and here after. Economy is one of fundamental need to support the religion and society development. In Islam Ziswaf (Zakat, Infaq, Sedekah and Waqf) well known as basic capital to help among Moslem and others.

The Study of Islamic Philanthropy (ZISWAF) is oriented for public needs (Sabiq, 1983: 378. Also at Rafiq, 2003: 491492). Based on the data from Ministry of Religious affar shown that the quantity of islamic philantropy from land wakf in this country $2.686 .536 .656,68 \mathrm{~m} 2$ or $268.653,67$ ha where is located on 366.595 location in Indonesia (Direktorat Pemberdayaan Waqf, 2006:83, look at Document of Religious Affair, 2009).

The study of asset of philanthropy show us, there are 2,7 juta $\mathrm{m} 2$ at 2007, it's wider that DKI Jakarta. At 2012 this potency added by 3 million $\mathrm{m} 2$ at 4.666 location Indonesia. An other side data from Republika (Monday, 02 Maret 2009) zakat also can be collected Rp 19 trillion/ year but BAZDA collected it only Rp 900 billion at 2008. This potency are very big chance to improve the function and fundraising of Philanthropy in Indonesia context as the biggest potency around the world.

Based on this condition, Indonesia has big chance for develop this country and ideally Islamic philanthropy ZISWAF can contribute more on improving the productivity of Islamic economic comprehensively. Indonesia have faced many problems to build up this potency in giving healthiness contribution for this country (Republika, 8 Juli 2008). This is compared by management of Islamic philanthropy on Middle East for example Arab Saudi, Mesir, Qatar, Kuwait and others where they had developed further. For instance Singapura manage WAREES (Waqaf Real Estate Singapore).

Based on the data, the majority of nazhir or amil worked as secondary duty. They did not give salary (84\%), and fully as worker in this improving Islamic fhilantropy only (16\%). Ziswaf was managed by personal Moslem $(66 \%)$ traditionally, and manaede professionally (16\%) and under institution $(18 \%)$. The other problem also founded by the center of language and culture (PBB) UIN Syarif Hidayatullah at 2006 from 500 respondent of nazhir at 11 Province that Problem management of Islamic philanthropy (waqf) most of them managed silently $(77 \%)$ than productive $(23 \%)$, for mosque $(79 \%)$ and more focused on village $(59 \%)$ than in city $(41 \%)$. This unimproved Islamic filantropy based on Syafi' i Antonio opinion is caused by management and human resources factor (Djunaidi dan al-Asyhar, 2005: v-vi).

This paper is to discuss about societal economic empowerment, focus on waqf analysis as a potential real asset owned by Muslim communities in the Islamic institutions. The great Javanese coastal mosque in fact has productive economic waqf assets that are of high economic value. Empowerment of waqf assets is highly dependent on the management system guidelines and governance systems carried out by its stakeholders, namely nazhir of waqf mosque property. The large capital of the waqf assets of this mosque is ideally able to be understood by the stakeholders of the waqf power as capital for developing the welfare of the people.

\section{THE THEORIES OF ANALYTICAL WRITING}

The management pattern of waqf in Javanese mosques in this coastal area in the construction of Parson Functionalism can be categorized in the third conception, namely the function of integration. The management system of waqf asset 
management agreed upon in this institution is a system that is functionally interrelated and regulates the relationship between the third parts of other components (AGL), namely legal guidelines for waqf rules in the form of dynamic understanding of nazhir (adaptation), operational systems manage waqf in the form of goal attainment and value systems (integration functions) where all these functions lead to the necessity for the system to have the ability to maintain solidarity and cooperate among fellow members of the institution (Latency) (Aliman, 2005,117).

Based on the structural-functional theory of Talcolt Parson, the waqf rules understood by the nazhir waqf in the Javanese Grand mosque became a function of adaptation which served as a guiding center for management of the waqf of the Great mosque in accordance with social dynamics. In the context of waqf institutions, this organizational system will run well, if it has prerequisites that maintain the balance of the continuity of the system. Talcot parson expresses functionalism in an organizational structure by pointing to the form of the unified construction of each of the interrelated and influencing fields. This formed system requires 4 things, namely Adaptation, Goal Attainment, Integration and Latency.

The theoretical construction of functional structural applied in waqf institutions is comprehensive and recognizes the importance of interaction between members and their internal and external environment. Analysis of this functional structure also expresses views on static institutions in addition to the structural functional perspective by minimizing the growth, change and imbalance of institutions. As a theoretical framework, functional structural is a description of the structure of the organizational dimensions and functions of the institution with the same approach (Leskie and Korman, 1989).

In a functional structural approach in the sociological realm (Parsons), the whole function parts are seen as reciprocal relationships. This follows the line of thought of social anthropologists who conclude that one cannot understand the specific aspects of social life regardless of their environment. Thus functional structural is considered as one of the social institutions of the community that is functional. The structure of the institution is a part that can be evaluated in terms of achieving the objectives of the organization.

In discussing management functions, borrowing terminology Decenco and Robbin (1999: 5) management is the procces of efficient achieving the objectives of the organization with and through the people which requires functions; planning, organizing, leading, and controlling. In line with management's opinion is actually from actions (POAC); namely planning (planning), organizing (organizing), mobilization (actuating), and supervision (controlling) carried out to achieve the goal, through the utilization of resources owned. This management pattern also implies controlling the desired target institution (Terry, 1977: 4).

There are three main reasons needed by management by all organizations, especially waqf institutions (Handoko, 2009: 6-7), namely to achieve goals, to maintain a balance between conflicting goals, and to achieve efficiency and effectiveness. Decenco and Robbin (1999: 5) state the importance of resources in achieving managerial effectiveness that are expected to be maximally achieved through measuring effectiveness by comparing the real results achieved with expected goals. Managerial performance is the result of the work behavior of leaders and managers in achieving organizational goals effectively. The intended performance is performance in carrying out management functions which include planning, organizing, mobilizing and monitoring functions.

Based on the Indonesianist context, Shafi'i Antonio offered an offer of 3 management concepts that were applied to social institutions in Indonesia. These three patterns were initially used as a period of periodization of waqf management. Based on this conception, the next question is how is the governance system implemented so that it becomes a governance behavior that becomes the norm (which pattern) is carried out by the management in achieving the institutional vision? So how are the choices of Nazhir's actions in determining the segmentation of governance developing the waqf assets of the mosque.

\section{FUnCTIONAL STRUCTURE DYNAMICS OF THE POWER OF ATTORNEY PROPERTY OF THE GREAT MOSQUE OF THE COASTAL JAVA}

A prosperous society is a society that is desired by humans in various social communities. This welfare can be achieved by one group and the maximum inadequacy can be achieved by other social communities, even though the community groups depart from the same capital. The long journey of the four Great mosques which have the same historical roots in terms of legality of ownership of mosque waqf property proves this condition.

Since the colonial rulers to the rulers of the old order in the course of the history of the Great Mosque of Demak, Semarang, Kendal and Kaliwungu experienced various dynamics. Questioning the purpose and functional properties of this coastal Javanese Great Mosque's waqf assets, which are quite fundamentally traceable are those of the contract made by the waqf of mauquf. Juridically, the structure and function of each of the nazhir wakaf of the coastal Javanese Great Mosque is sourced from KMA No. 92 of 1962 based on Stanblat No 605, jo Besluit Governor General Van Ned Indie, do 12 August 1896 Number jo do 6 November 1912 No. 22 C Bijlad 7760.

From the initial purpose of granting this land, in the course of its history these lands were better known and legalized as waqf land for the benefit of the mosque. becoming BKM as waqf manager until now there has been no change in regulation from the ministry of religion. The waqf for this historic mosque has a clear legal foundation, that the Great Mosque of Demak, Semarang, Kendal, and Kaliwungu have rice fields as banda mosques, which are fons to finance the maintenance and repair of mosques, courtyards and sacred tombs of the guardians in around the neighborhood of each mosque. This provision is contained in KMA No.32 of 1962 with the affirmation of the status of Semarang Kendal, Kaliwungu and Demak mosques as waqf mosques and not merely objects (buildings), but also as legal subjects who are entitled to own property and manage it.

Referring to the goal attainment point $(\mathrm{G})$, the waqf of the Great Mosque is clearly to be utilized in the sectors set out in the guidelines, the management guidelines for waqf. This 
guideline is a waqf guideline that refers to Islamic law regulations and UUW regulations that are ratified by the state, in addition to the joint rules for allocation of waqf allocations to the welfare of the mosque and the surrounding community.

In general, the duties and responsibilities of Nazaf waqf who have a mandate in the form of land are the utilization of waqf land and maintaining it. From its history the wealth of the waqf of the Great Mosque of Demak is a form of land inherited from Raden Fatah (Kartasapoetra, 177: v). The land certificate of the waqf inherited from Raden Fatah is in the name of the BKM on the orders of the Minister of Religion where the BKM is a legal entity that has ownership rights to the waqf land. The waqf legal entity that was formed at the beginning was oriented to the public interest which was considered as shared ownership (Ash-Shidiq1, $\mathrm{t} .:$ 194). This is where the strategic choices of BKM administrators become tested to progressively run progressively or conversely stagnate in status as Nazaf waqf.

In the perspective of Islamic law and the positive legal perspective the Waqf Law No. 42 of 2014, Nazhir as the stakeholder in the management of waqf property assets is responsible for:

1. Growing public awareness on empowering community welfare, especially the distribution of social justice philanthropy for orphans, the needy and the du'afa '.

2. Developing the quality of human resource management and the younger generation through improving education, training, and skills to improve HR capabilities.

3. Improve relations and cooperation with other organizations that can improve the development of the institution.

4. Developing waqf assets becomes a productive endeavor for maximum results.

Based on the historical facts of the four coastal Javanese Great mosques, the pattern of management of waqf assets even though it starts from a pattern of management, mosquebased waqf "ala perbot mosque", in its historical development management patterns experienced differences, both in Kaliwungu mosque, Kendal and Demak and Semarang. The differences in managerial systems are discussed in more detail as follows.

\section{PATTERnS OF GOVERNANCE OF THE GREAT MOSQUE WAQF INSTITUTION}

Governance is part of the management of program arrangements launched by an institution. In the level of management of coastal mosque waqf, governance is one of the keys to the success of regulating, and developing waqf assets managed by the institution. This governance can work well or vice versa is strongly influenced by the choice of actions by institutional actors. There are three other fields in the organizational structure of the Kaliwungu mosque, namely the field of fortune and business services. The field of destiny oversees three parts, namely the Imaroh section, the Idaroh section and the Ri'ayah section.

The form of the institutional structure of the Kaliwungu mosque is different from the pattern of the structure of the kenazhiran wakaf of the Great Kendal mosque. There is a separate kenazhiran structure formed within the circle of the foundation of the Great Kendal mosque. Structurally nazhir and takmir in the context of the Great Kendal mosque are different, although the personnel occupying the structure are the same. This structural construction is actually more effective, but on the other hand this organizational structure model can create new problems, namely overlapping tasks and authority. Fragility occurs especially when the programs are carried out both in the mosque's destiny and in the kenazhiran wakaf area of the Great Kendal mosque.

Structurally the BP MAS institution, there is a top leader held by Hasan Thoha, but in the implementation of praxis programs, more are carried out by their respective fields including the asset development section. They move more, because of the authority and personnel, the management has the status of retirees who have more time and power of knowledge on the waqf assets of the Great Mosque of Semarang. This condition is different from the dynamics that occur in the BP MAS camp where the manager is mixed there are those who are retired and there are free business people who are not easily trapped in formalistic habitus. As for the governance of the development of productive waqf land assets assessed by the Nazhirs chosen with good standard management and safe from the risk of loss.

In the context of the Kaliwungu grand mosque, other management as an alternative management of waqf assets that are more productive, has not been maximally implemented. From the functionalization of the Nazarite structure of the mosque as the manager of the Islamic kingdom's waqf assets with their respective characteristics. The first waqf assets managed by takmir mosques doubles as the nazhir waqf, namely the waqf treasure in the Great Kendal mosque and the great mosque of al Muttaqin Kaliwungu seems to be managed with "traditional" management patterns.

The form of management of waqf assets by the BKM tends to be managed more openly, the majority of BKM refers to UUW No. 41 of 2004, especially the understanding that waqf can be in the form of movable or immovable property that can be developed productively. This productive form can be seen in the form of management in the development of waqf assets which are managed by a choice of land rental models for building leases, for meeting places and the development of other forms of "business" based on waqf land assets.

In the theory of power structure, the Nazis are "social elites" who are barely touched by criticism by the surrounding social circles (Foucault: 1980). The takmir who are at the same time the end of this waqf are

And to carry out duties as a Nazir who is so heavy, then a Nazhir should have the ability, including:

a) Ability or technical expertise, for example operating a computer, designing a room and more.

b) Expertise in communicating and interacting with the community, especially to parties directly related to waqf.

c) Conceptual expertise in order to produce waqf assets.

d) Be firm in making decisions, after deliberation and thought through carefully. Skills in managing time.

e) Including having maximum energy, risk taking, enthusiasm and confidence. 
His obligation of Nazhir in the Kaliwungu Grand Mosque at Kenazhiran in the Kaliwungu mosque is already in the form of a foundation. From the dynamics of changes in the tradition of the formation of structural managers who at first were very thick with trust in the figure of the figure, then switching to the form of the foundation seemed to be a symptom of a more "semi-professional" management

This is their choice in the institutional system, even though it is mentioned in the hadith in sharia that the person who manages the waqf property may take part of the proceeds. Even in article 12 UUW No. 41 of 2004 is written that: "In carrying out its duties Nazhir receives compensation from the net proceeds for processing and developing waqf objects whose amount does not exceed $10 \%$ (ten percent)".

The waqf treasure of the Great Mosque of Semarang is still in the power of the BKM Kab. Semarang while the management is technically submitted to the mosque management foundation. This management dualism has resulted in internal conflicts between the waqf managers of the Great Mosque.The facts on the ground that can be found along with the speakers of the management are that the management still seems to be "on the road", many waqf assets are neglected and have not been well managed. Another factor that appears in the management of the "product and distribution" of the waqf property of this mosque is based on the narrative of one of the activists of the Great Mosque of Semarang, "there is a management error in managing the waqf land. The inaccuracy of management since the beginning caused difficulties in empowering waqf assets in the form of immovable land of the Great Mosque of Semarang ".

The waqf property of the Great Mosque of Demak based on Minister of Religion Regulation No. 3 of 1973 which was previously named the Regional Mosque Welfare Agency (BAKESMASDA). The land that originally came from the legacy of Joko Tingkir when seizing power from Arya Penangsang was used as waqf land and now the land is certified in the name of BKM Kab. Demak (Akasah, 2006: 9). The land area owned is 3,469,679 $\mathrm{m} 2(346,9 \mathrm{ha})$ in addition to land from the development results, namely waqf land covering an area of $268,847 \mathrm{~m} 2$ (26.8 ha).

The 350 ha of land is leased to the Demak community by auction. In Islamic law, waqf lands which are then managed by Nazhir do not become neglected, in terms of fiqh called aldaerah (guardianship). Trusteeship is a legal power that gives the owner the right to control it and manage it and regulate its affairs by managing, prospering, and giving the results to those entitled to receive it (Shalabī, 1957: 112).

On the side of the explanation of its organization, Nazhir's institution is contained in article 9 letter $b$ that Nazhir must fulfill the following requirements:

f) The management of the organization concerned fulfills the requirements of the individual Nazar as in paragraph 1. And

g) Organizations engaged in the social, educational, social and / or religious fields of Islam.
V. VARIETY OF PATTERNS OF GOVERNANCE FOR

ENDOWMENT ASSETS OF THE GREAT MOSQUES FOR ISLAM AND SOCIETAL DEVELOPMENT

\section{A. Processing of waqf assets based on agrarian patterns}

The management pattern is a form of action by waqf actors in choosing forms of waqf management based on guidelines from their cognitive knowledge. Different structures both between the structure of the mosque's destiny and the BKM both have their own peculiarities. Based on the responsibility as a kenazhiran structure in the context of the Demak BKM, the choice of the pattern of governance of the waqf land of the mosque run by Nazhir on productive paddy fields is by leasing through an auction system (Poerwadaminta, 1985: 580).

The choice of governance with the auction path is rationalistic action on the end of waqf assets in the form of productive land. And in today's development the land is still productive agricultural land. The auction is not only carried out by the grand mosque of Demak, part of the productive agricultural land of the Great Mosque of Semarang's waqf land has been identified, BP MAS as the executor of MAS waqf management manages it by leasing other than some land which is "occupied" by the community without paying rent .

Auctions are the main choice for BKM Kab. Demak. Sugianto revealed that the auction system is easier to run, not too troublesome and not too high risk compared to other management patterns. Nazhir Wakaf Kaliwungu mosque in several periods before managing its own land of productive land waqf covering an area of 23 ha. The management was carried out by auction, but after management was taken over by self-managed takhirhir of waqf takmir, the results were doubled. Once the harvest gets a range of 400 million and this amount is the result of a year's auction.

In Islamic law when a contract does not violate syara with sharih texts, and is not contrary to the rules of sharia and its basics, then the contract can be carried out (Salim, 2008: 28). Sociologically, Nazhir's behavior in the circle of waqf asset management becomes diverse in accordance with the diversity of ideas and external factors.

\section{B. Pattern of Management of Waqf Assets in Business Development}

As a system, the pattern of coastal management of the Javanese Great Mosque's assets adapts to the forms of period development, there are some patterns that are maintained that are applied by developing a more progressive management pattern. The diversity of conditions of each nazhir in the four great Javanese mosques of the coastal area became categorized as the form of development of each waqf property owned.

In the context of the Great Mosque of Semarang, the forms of economic empowerment of the waqf of the Great Mosque of Semarang, run in a variety of businesses including the first empowerment of the waqf of the Great Mosque of Semarang in the form of gas stations (on Citarum Road) which were originally owned by Ny. Susanti Dian Safitri (daughter of Mayor H. Soetrisno Soeharto) who was later sold to Mr. H. Mardianto as Governor of Central Java along with cafe, workshop and everything that stood on the land for 1.5 billion rupiah and carried out handover to dated November 5, 2004. management of waqf assets in the form of a Public Fuel Filling 
Station (SPBU) was able to generate a profit of Rp. 50 million. Professional governance pattern in the form of this gas station with a pattern of profit sharing system for gas station management which is based on the percentage of SPBU distribution results in accordance with the shaded areas.

Another form of development of waqf assets managed by a more professional governance system is the purchase of a Bojong hotel located north of MAS in 2010. For this purchase BP MAS implemented a fundraising system through waqf moneyraising movements from the community and the congregation collected more than Rp. 1.5 billion. This hotel was purchased at a price of Rp. 3.5 billion complete with all the furniture.

Another form of governance that is categorized as semiprofessional management by BPMAS is the development of the Agro Mas Main Market. As planned, Agro Mas Market is not designed as a traditional market, but will be used as a wholesale market for fruits, vegetables and agricultural products on a scale large which holds around 700 traders ".

The form of management of MAS waqf assets that are in the business domain is the empowerment of waqf lands around the mosque. Among the waqf assets leased are shop rentals, land rentals for institutions, building rentals for meetings, rental of buildings for PBAT (Integrated Arabic Language Development), rental of land for agents and shops.

In addition, vacant land is empowered for office rentals, development of parking lots and souvenir sales. The empowerment of waqf objects in Weleri, Demak, Semarang in the form of rented arable land or arable land auction. In the context of the Kaliwungu mosque, the form of management of waqf property in addition to agricultural agrarian patterns is in the form of renting parking lots near the mosque because of its strategic location near the market, a system used to manage the property by leasing for 2 years. Apart from that, the input from the charity box every Friday is IDR 6,000,000 per month and from the big box IDR 5,000,000 every three months.

The management pattern in the institutional context of coastal Javanese waqf institutions can also be understood as patterns of governance of the actors choosing their actions in managing waqf assets. The choices of Nazhir's actions actually do not run partially, but they are influenced by their logical reasoning. Like the choice of Nazhir's actions in developing the results of waqf assets in the form of additional paddy fields, the results could be to increase the assets of other waqf institutions.

From the analysis of these patterns, the pattern of waqf management in Coastal Java mosques can be classified into a number of bases of management patterns, namely first traditional governance, both semi-professional governance and the three patterns of professional governance. The three forms or patterns of management are natural implications arising from the diversity of typologies of the views of the nazhir wakaf of the great coastal mosque. This means that the typology of cognitive understanding of waqf as legislation, guidelines for waqf legal order make the Nazar's guideline in carrying out the management pattern of waqf of the Great Mosque mandated by Wakif.

\section{CONCLUDING REMARKS}

From the description above, at least the pattern of management of institutions and waqf assets of the coastal Javanese Great Mosque can be categorized as follows:

\section{A. Traditional Management Patterns}

Traditional management meanings are referenced from the existence of variants of the identity and management patterns of managed institutions and waqf assets. This waqf management theory was initiated by M. Syafii Antonio. Some indications of this traditional waqf management pattern are:

\section{i. Stagnation of understanding of waqf.}

Understanding of the waqf management actors in this traditional management pattern still sees waqf as pure teachings included in the category of mahdhah worship alone. Assets that are represented by dominant immovable objects.

ii. May or not exchange of waqf assets.

The majority of wakif from Indonesian Muslims in this matter, tend to refer to the conservative view of Imam Shafi'i which states that waqf assets should not be exchanged "for any reason". In the case of the mosque, Imam Shafi'i stressed that he should not sell the waqf mosque absolutely, even though the mosque collapsed.

iii. Nazhir Wakaf is still patterned in traditionalistic institutions.

Habits of the people tend to want to partially share their wealth by entrusting themselves fully to someone who is considered a figure in the surrounding community, such as kyai, ulama, ustadz, ajengan and others to manage wakaf assets as nazhir. This traditional management pattern is predominantly based on the fame of the figure, not yet based on an adequate vision of empowerment, whereas regulatively UUW has a management pattern that surpasses the traditionalistic waqf governance pattern (Junaidi, 2006: 1).

\section{B. Semi-Professional Management Patterns}

The semi-professional pattern is a waqf management pattern whose condition is relatively the same as the traditional phase, but this management pattern has begun to be developed with a pattern of empowering waqf professionally, even though it has not been maximized. For example, management of waqf institutions has begun to implement targeted management patterns with neat institutional programs. The administrative side has begun to be arranged with financial records that are regularly reported.

Some examples of this semi-professional pattern are the development of waqf land assets with buildings for meetings, weddings, seminars and other events. Mosque institutions that have implemented a pattern of semi-professional waqf management with waqf-based mosques are like Sunda Kelapa mosque, Pondok Indah mosque, At-Taqwa Pasar Minggu mosque, Masjid Ni'matul Ittihad Pondok Pinang (all located in Jakarta). In the context of educational institutions, this pattern of semi-professional management empowerment has been carried out by the As-Salam Modern Islamic Boarding School Gontor, Ponorogo.

\section{Professional Management Patterns}

This professional waqf management system is characterized by increasingly strong formal regulatory 
support. The waqf law guidelines are not only based on the jurisprudence of the jurisprudence, but have been strengthened by positive law in the legal order of the state. Birth of UUW No. 41 of 2004 is the legal guiding base as the legal force for the development of professional management waqf.

In this phase of professional waqf management, the most prominent example was the emergence of cash waqf ideas which were rolled out by economic figures from Bangladesh, M.A. Mannan. In the Indonesian context, the productive waqf movement managed by a professional management system had been initiated by Dompet Dhuafa some time ago with the idea of investment endowments.

Other institutions are the PPPA Daarul Quran, the Surabaya al Falah institution and several indications of professional management being pioneered in the waqf institutions of the coastal Javanese Great Mosque. The spirit of empowering waqf potential in a professional manner, empowering waqf supported by formal regulations, such as the birth of the new Waqf Law, the role of the Regional Autonomy Law, the role of the Regional Regulations, national monetary policy, tax laws and so forth. These regulations seem to be inspired by empowerment of waqf carried out by "Muslim countries", such as Egypt, Turkey, Saudi Arabia, Jordan, Qatar, Kuwait, Morocco, Bangladesh, Pakistan, Malaysia and so on.

The development of periodization and the pattern of professional governance has become a social fact that waqf lands actually have a strategic position that must be managed more optimally and professionally on the wider vision of people's welfare.

There are several criteria for handling professional waqf, namely the governance of institutional management patterns, there are efforts in the form of planning, actuating, controlling and evaluating which are carried out consistently. According to Syafi'i M. Antonio, in addition to this stage, the pattern of professional waqf management has been realized, there is a good financial system, implemented transparency and accountability, and is run by professional and competent human resources.

From the indication of the professionalism of the waqf managers in four great Javanese coastal mosques, there are several indicators of management characteristics that have been professionally carried out. There are still many improvements both hard skills and soft skills, although there are still efforts to improve the growth of governance and maximizing the management results . According to Achmad Djunaidi (2008: 65-126), the new paradigm of waqf in Indonesia which manifests itself in the productive waqf model has two things, namely the principle of the new waqf paradigm and aspects of the new waqf paradigm. The principles of the new waqf paradigm are: (1) the principle of eternity of benefits; (2) the principle of responsibility; (3) management professionalism; (4) the principle of social justice. While aspects of the new waqf paradigm are: (1) renewal of understanding of waqf; (2) professional management management system reform; (3) nazhiran management system (human resource management); and (4) waqif recruitment system
As for institutions that have started to grow with large assets, there are various conflicts that have occurred in these waqf institutions. This conflict, both the pro and the contra in the case of each management of the coastal wakaf property of the great Javanese mosque is a common occurrence in a stream of social change in society. In the next stage, the conflict that had tapered and affected the theme of the Friday sermon and in the light conversations between Nazhir in each of the great coastal Javanese mosques.

The social facts that revolve in the dynamics of waqf wealth governance, there seems to be a conformity with Robertson's (1988: 519) view that the theory of social change conflicts considers that various changes are caused by tensions between competing interests in society. There are some typical figures as nazhir waqf in the great Javanese coastal mosques, and forms of action to resolve the Nazir conflict. Among others are:

1) A typical rough conflict, is a conflict that is very visible to the social surface due to differences that arise in the dialects of managing mosque waqf assets. Such conflicts occur in the Great Mosque of Semarang and Demak, the respective periods as described in the above discussion.

2) A typical semi-rough conflict, this type of conflict is a conflict that is still somewhat stored in each social actor in this context conflict occurs within the internal authority of the waqf manager. This conflict pretends to be a rough conflict when it is not managed strategically and managed productively from a stakeholder that is more authoritative and sometimes judged to be more senior.

3) Typical subtle conflicts. This conflict is a conflict resulting from the clash of views from social actors relating to various interests that have influenced them. This conflict exists but not so far as to bring about strong socila turmoil. This conflict can be overcome easily because of the level of the feud which is relatively not heavy, conflict of management patterns that are subtle soft conflict.

In the adaptability process of the managerial governance of the waqf mosque of the Great Javanese mosque, there are several challenges that become obstacles and at the same time stop the growth of the execution of the waqf at the great coastal mosque. The first challenge is in the realm of thinking and the diversity of views on endowments and about the laws that surround them. The second challenge is the lack of human resources management of waqf. The third challenge is low human resourses that still have old skills and abilities and there has been no renewal of new management resources with adequate adaptability.

The fifth challenge is the wave of changes outside the institution and stakeholders and the waqf institutional system that are increasingly moving increasingly complex. The sixth challenge is the existence of new regulations that are rolled out to the stakeholders of the waqf authority. From the perspective of religious ideology theory, waqf is an institution that is very sacred by some of the waqf kyai-nazhir. Religious ideology has a role in encouraging social change in society. In the dynamics of waqf governance there are multiplier effects (various influences). Endowments developed into the community will return to the mosque. The community is prospered, so the mosque will also prosper. The weakness of the system while in the institution of managing waqf of the 
great Javanese coastal mosque, especially in the kenazhiran wakaf of the Great Mosque of Semarang are:

1) In the dualism of management which is confused with the authority of the owner of the power of waqf governance.

2) On the latency of the weakness of the different cultural systems that bind between the waqf administrators between the actors in the Ministry of Religion's circle and the circle of the inevitability of the MAS who are predominantly kyai and businessmen

3) In a weak management management system because of the certainty of managers who are tugging at each other. The system (integration) is not easy to implement because of the long vortex of conflict. It has not been able to determine the management pattern that binds all good governance in full.

4) In the neglected guideline (adaptation) system, the levels of the waqf operational system have not been able to move due to the dualism of management.

5) Goal attainment of operational patterns of waqf management that have not been thought of because of the jealousy and lack of trust in each of these institutions.

In Talcot Parson's functional perspective (Goodman, 2003: 127), as a system that is seen as a unity of actors in an institutional system, the system is used as an actor controller and not at a press point on the way actors create and maintain systems. In this case the behavior of the management of waqf assets in Kaliwungu appears that Nazhir has done what is his duty, namely utilizing the waqf property such as cultivating rice fields which the results can be used to prosper the mosque and even get more balances than the mosque expenses, as well as the endowments which is used for parking lots and also as a result of bathroom rentals.

In such a substance the target as a category of "traditional" governance in the management of waqf assets has been carried out. However, this pattern has not reached the limits of semiprofessional and especially professional governance. Even though the management carried out by the Kaliwungu Grand Mosque has looked good without much turbulent conflict, according to the acknowledgment of the chairman of the waqf institution the mosque is still looking for a new format of management, because until now Nazir in Kaliwungu and Kendal is still traditional, and has not led to a more productive economic development.

Citing the Kohaf theory of waqf assets managed by the private sector will be more productive and progressive than waqf managed by the government. This theory is true in the Kaliwungu and Kendal cases, but this is not true in the Demak case. Waqf managed by BKM Demak is quite good compared to Kendal. Even though in Kendal the managers themselves are retirees from the Ministry of Religion. So that institutionally the Semarang waqf institution should be more ideal when it is able to surpass the long period or conflict phase.

In fact, the progress or productivity of waqf assets management is strongly influenced by the ability of the actors who manage waqf. The pattern of governance of the operationalization of work programs and organizational rules is a strong foundation to support the organizational program, overseeing its vision and mission in an effort to garner community welfare with principles based on the regulation of Islamic shari'ah.

\section{REFERENCES}

[1] Abd al-Baqī, Ibarahim Mahmud, 2006, Daur al-Waqf fi Tanmiyat al-Mujtama' al-Madany (Namudzatun alAmanah al-'Ammah li al-Auqof Bidaulat al-Kuwait), alKuwait: al-Amanah al 'Ammah li al-Auqof).

[2] Ahimsa-Putra, Heddy Shri, 2001, Strukturalisme LevisStrauss,Mitos dan Karya Sastra, Yogyakarta: Galang press.

[3] Al-Kabisī, Muhammad Abid Abdullah, 2004, Hukum Wakaf, Pentrj. Ahrul Sani Fathurrahman, dkk.(et.al.), Jakarta: IIMaN Press.

[4] Antonio, Muhammad Syafi'̄̄, 2007, "Pengantar Pengelolaan Wakaf Produktif", dalam Achmad Djunaidi dkk, Menuju Wakaf Produktif, Jakarta: Mumtaz Publishing.

[5] Anshori, Abdul Ghofur, 2006, Hukum dan Praktek Perwakafan di Indonesia,Yogyakarta: Penerbit Pilar Media.

[6] Asy-Syāfi'̄̄, Muhammad Ibn Idrīs, 1990, al-Umm, Beirut: Dār al Fikr al-Arabī.

[7] Asy-Syairazī, Abu Ishak ibn Ibrahim ibn Ali Ibn Yusuf al-Fairuz Abadi, tt, Al-Muhazzab fi al Fiqh al Imam asySyafi $\overline{1}$, tanpa Kota: Syirkah Nur Asia.

[8] Az-Zuhailī, Wahbah, 1989, Al-Fiqh al-Islamī wa Adillatuhu, Beirut: Dār al-Fikr.

[9] Baqir, Zein Abdul, 1999, Masjid-Masjid Bersejarah di Indonesia, Jakarta: Gema Insani.

[10] Bamualim, Chaider S. (eds), 2005, Revitalisasi Filantropi Islam (Studi Kasus Lembaga Zakat dan Wakaf di Indonesia), Jakarta : Pusat Bahasa dan Budaya UIN Jakarta.

[11] Babbie, Earl, 1998, The Practice of Social Research, Westford: Wadsworth Publishing Company.

[12] Bernard,H. Russel, 1994, Research Methods in Antropology: Qualitative and Quantitative Approches, London: Sage Publication.

[13] Departemen Agama RI, 2003, Fiqih Wakaf, Direktorat Wakaf Depag RI, Jakarta.

[14] Djunaidi, Achmad (et.al), 2006, Menuju Era Wakaf Produktif Sebuah Upaya Progresif untuk Kesejahteraan Umat, Jakarta: Mitra Abadi Press.

[15] Denzin C. . Norman\& Wanna S, Lincoln, 1997, Handbook Qualitative Research, (terj.) Sage Publication, USA.

[16] Geertz, Cliford, 1960, The Religion of Java, The Free Press.

[17] Geertz, Cliford, 1989, Abangan, Santri, Priyayi dalam Masyarakat Jawa. Jakarta: Pustaka Jaya

[18] Gidens, Anthony \& David Held, 1987, Perdebatan Klasik dan Kontemporer Mengenai Kelompok, Kekuasaan dan Konflik, Jakarta: Rajawali Press.

[19] Hadi, Sutrisno, 1985, Metodologi Research, Yogyakarta: Fak. Psikologi UGM.

[20] Hasanah, Uswatun, 1997, "Peranan Wakaf dalam Mewujudkan Kesejahteraan Sosial: Studi Kasus Pengelolaan Wakaf di Jakarta Selatan", Disertasi Pascasarjana IAIN Syarif Hidayatullah Jakarta.

[21] Holsti, C. R., 1969, Content Analysis for the Sosial Science and Humanities, Canada: Departement of Political Science University of British Columbia.

[22] Koentjaraningrat, 1990, Pengantar Ilmu Antropologi, Jakarta: Rineka Cipta

[23] Mastuhu, "Penelitian Agama Islam: Tinjauan Disiplin Sosiologi", dalam Mastuhu dan M. Dede Ridwan, 1998, Tradisi Baru Penelitian Agama Islam: Tinjauan Antar Disiplin Ilmu, Jakarta: Pusjarlit-Nuansa. 
[24] Nawawi, Hadari, 1993, Metode Penelitian Bidang Sosial, Yogjakarta: Gajah Mada University Press, Cet. 6

[25] Imām al-Bukhārī, 1989, Şahīh al-Bukhāri, Beirut: Dār alFikr.

[26] Moleong, Lexy J., 2000, Metodologi Penelitian Kualitatif, Bandung: PT Remaja Rosda Karya.

[27] Nadjib, T. A. dan Ridwan al-Makassary (Ed.), 2006, Wakaf, Tuhan dan Agenda kemanusiaan, Jakarta: CSRC UIN Sahid.

[28] Robey David (Ed.), 1973, Structuralism an Introduction, Oxford: Oxford Uni Press.

[29] Sayyid Sabiq, Fiqh al-Sunnah, Beirut: Dār al-Fikr, 1983).

[30] Smith, Philip, 2001, Cultural Theory: An Introduction, Oxford\&Massachusetts: Blackwell Publishers.

[31] Soekadijo, (Terj.), 1981, Antropology Budaya Suatu Perpsektif Kontemporer, Jakarta: Penerbit Erlangga.

[32] Syam, Nur, 2005, Islam Pesisir, Yogyakarta: LKiS.

[33] Turmudi, E., Struggle for Umma Changing Leadership Roles of Kiai in Jombang East Java, alih bahasa Supriyanto Abdi, LKiS, Yogyakarta, 2003.
[34] Turmudi, E., 2004, Perselingkuhan Kiai dan Kekuasaan, Yogyakarta: LkiS.

[35] Thohir, Mujahirin, 2001, Menyoal Kota Santri Kaliwungu (Sebuah Ikhtisar Berkaca Diri), Kendal: Panitia Festifal Al-Muttaqin Kaliwungu Kendal.

[36] Thohir, Mujahirin, 2006, Orang Islam Jawa Pesisiran, Semarang: Fasindo.

[37] Thohir, Mujahirin,(Ed.), 2011, Refleksi Pengalaman Penelitian Lapangan Ranah Ilmu-Ilmu Sosial Humaniora, Semarang: Fasindo.

[38] Wadjdy, Farid dan Mursyid, 2007, Wakaf dan Kesejahteraan Umat (Filantropi Islam yang Hampir Terlupakan), Yogyakarta: Pustaka Pelajar.

[39] Weber,M., 1973, The Routinization of Charisma", dalam "Social Change", New York.

[40] Zahrah, Muhammad Abu, 1971, Muhadharat fi al-Waqf, Beirut: Dar al-Fikr al-Arabi.

[41] Ziemek, M., 1983, Pesantren dalam Perubahan Sosial, Penerbit P3M, Jakarta.

[42] Tholhah Hasan (BWI)) (2009), Peran LKS di Era Wakaf Produktif, http://bw-indonesia.net/, Senin, 09 Maret 2009, accessed 10 Agustus 2009 